\title{
THE DEVELOPMENT OF TVET EDUCATOR COMPETENCIES FOR QUALITY EDUCATOR
}

\author{
Ismail, A. ${ }^{1}$, Hassan, R. ${ }^{1}$, Abu Bakar, A. ${ }^{2}$, Hussin, H. $^{3}$, Mat Hanafiah, M. A. ${ }^{3}$ \& \\ Asary, L. H. ${ }^{4}$ \\ ${ }^{1}$ Universiti Tun Hussein Onn Malaysia, \\ 86400 Batu Pahat, Johor, Malaysia. \\ ${ }^{2}$ Ministry of Higher Education, \\ 62200 Putrajaya, Malaysia. \\ ${ }^{3}$ Universiti Teknikal Melaka, \\ 76100 Melaka, Malaysia. \\ ${ }^{4}$ Universiti Teknologi Malaysia, \\ 81310 Skudai, Johor, Malaysia.
}

Correspondence author email: affero@uthm.edu.my

Received March 17 $7^{\text {th }}, 2018 ;$ Accepted June $25^{\text {th }}, 2018$

\section{ABSTRACT}

\begin{abstract}
Malaysia is taking steps to strengthen policy guidance and regulatory frameworks for technical and vocational education and training (TVET) and to improve its governance and programme implementation for economic transformation and sustainable development. The transformation requires that TVET educators are well prepared to face the challenges of globalization so that Malaysian educators can stand tall and be committed to support an education system that can fulfil the needs and aspirations of a nation. The objective of this paper is to propose the effective competency of a TVET Educator in Malaysia context based on the four series of focus group discussion (FGD). This paper explains the development process of the TVET Educator competencies and the final component generated from the professional and expert in TVET Educator's Education. The outcome this study concludes the three main components namely Personal Traits and Professionalism; Teaching and Learning and Training and Technical and Innovation. The development of these competencies is to ensure that the quality TVET Educators produce competent TVET graduates who are capable to meet the requirement of industries and professional bodies. Nevertheless, it is important for the TVET providers, industries, communities and the Government to collaborate towards achieving a status of high income nation
\end{abstract}

Keywords: TVET educator competency; quality TVET educator; TVET Graduates; teacher standards

DOI: https://10.30880/jtet.2018.10.02.004

Vol. 10, No.2| December 2018| ISSN 2229-8932 Journal of Technical Education and Training (JTET) |38 


\section{INTRODUCTION}

Described in the $11^{\text {th }}$ Malaysia Plan as a Game Changer, TVET is a catalyst for economic growth and is expected to fill the gap of skilled workers of $7 \%(5,352)$ by 2020 . Across all disciplines, about $60 \%$ of the 1.5 million jobs that will be created during the Eleventh Plan will require TVET-related skills $\left(11^{\text {th }}\right.$ Malaysia Plan, 2016). However, it is important that the supply and demand of the work force will not be mismatched in terms of quantity and disciplines. Main ministries related to TVET, have unanimously agreed that they have to enhance the curriculum to be industry-led, improving the governance of the TVET institutions, and streamlining of TVET qualification within the Malaysian Qualifications Framework (MQF). There are various TVET institutions in Malaysia such as 1) Ministry of Higher Education, 2) Ministry of Education, 3) Ministry of Human Resources, 4) Ministry of Youth and Sports, 5) Ministry of Women, Family and Community Development, 6) Ministry of Defence, 7) Ministry of Agriculture, 8) Ministry of Tourism and Culture, 9) State governments and 10) Private institutions. In striving to produce quality graduates, these institutions are required to recruit competent TVET educators to ensure the focus of developing skilled workers is achieved.

UNESCO has redefined TVET as comprising of education and training and skills development relating to a wide range of occupational fields, production, services and livelihood. TVET as part of lifelong learning can take place at secondary, post-secondary, tertiary and includes work based learning and continuing training and professional development that may lead to a qualification. It includes a wide range of skill development at national and local context. It needs to consider literacy, numeracy skill, transversal skills and citizen skills which form the integral part of TVET (UNESCO, 2015). Therefore, the summary of TVET can be clustered into three main attributes which are 1) Inclusive of education and training processes; 2) Comprehensive shaping of talent; and 3) Crossing all occupational fields.

In line with the TVET definition and aims, one of the main key player for this purpose falls to TVET educators. Quality TVET educator becomes a focus of many TVET stakeholders in recent years. As for Malaysia, under the $4^{\text {th }}$ shift of Malaysia Education Blueprint 2015-2025 (Higher Education), an initiative to produce quality TVET educators has been outset with purpose of preparing quality graduates. In this context, a TVET Educator is a person whose function is to impart knowledge or know-how to students or trainees in a TVET institution. The term educator could be referred to teachers at schools; lecturers at colleges, traditional universities, comprehensive universities, and universities, and universities of technology; trainers in workplaces; facilitators, assessors, moderators, and people teaching, educating, training, facilitating or assessing learners across the board (UNESCO UNEVOC, 2013).

\section{PROBLEM STATEMENT}

The limited experience of educators could be one of the potential reasons behind students' limited awareness of practical applications as well as readiness to meet industry's professional and technical requirements (PricewaterhouseCoopers, 2016). Therefore, the development of this competency could be used as a tool in producing quality TVET educators. On the other hand, one of the biggest problems in the educating profession is the lack of promotion for educators and proper guidelines for promoting educators. Essentially, promotion must be based on merit and merit has to be about quality, and quality must be about skills and knowledge of the educators. It is believed that good educators must remain in the classrooms and good administrators may not be good educators. Therefore, this paper focuses on the development of TVET educator's competencies covering all important aspect of quality educator that will contribute to their professional development. 
As aptly put by Waters (2009), there may be global warning but global yawning is definitely on the rise in the classrooms of the world that includes teaching and learning, technical aspect and the professionalism. Meanwhile, Furlong's (2008) idea of remodelling of the teaching workforce does not sound too farfetched. It involves rethinking the certification, promotion criteria and processes. The suggestion is that to look at the educator's certification as; assistant educator, novice educator, principal educator, master educator and chartered educator.

\section{OBJECTIVE AND METHODOLOGY}

The main objective of this paper is to describe the set of skill competency for a TVET Educator. The important part of this paper is to explain the outcome of the Malaysia TVET Educator competencies based on the four series of focus group workshop that was conducted since 2015 until 2018. The focus group involved 12 experts from Regional Cooperation Platform (RCP), Ministry of Higher Education, Malaysia Polytechnic, Ministry of Human Resources, Ministry of Education, Malaysian Qualification and members from Malaysia Technical University Network (MTUN). The workshop was conducted and discussion was made based on the thematic approach. The consensus among the group was resolute after a thorough discussion. The session was recorded and transcribed for the analysis to come out with final components of the competency. These competencies were developed based on the standard development design namely Development of Standard and Curriculum (DESCUM), Work Process Based and CDIO (Conceiving, Developing, Implementing and Operating). The final draft of this standard was scrutinized and agreed upon by the experts and professional from various stakeholders. This document has been developed while reviewing University and University Colleges Act 1971, The Private Higher educational Act 1996, Education Act 1996 (Act 550), National Skill Development Act 1996 and Malaysian Qualifications Agency Act 2007.

\section{LIMITATIONS OF STUDY}

This study is basically a project funded by the Ministry of Higher Education to enhance the quality of TVET graduates. Therefore, the landscape of this study revolves around lecturers or educators in higher education level. The component described in this study is aimed to act as the guideline to develop effective TVET educators. The competencies may be used in the planning and designing the TVET educator's curriculum for re-skilling and up-skilling and even for the staff recruitment. Looking at its comprehensive and thorough explanation, these competencies can be expanded to various ministries and TVET agencies at all levels.

\section{TVET EDUCATORS IN MALAYSIA}

The present scenario of TVET educator education in Malaysia is one of trials with some tribulations which consequently provoked the temptation for change through transformation. The transformation is to ensure that the TVET educators of the future generation are truly well educated and well prepared to face the challenges of globalization so that Malaysian educators can stand tall and be committed to support an education system that can fulfil the needs and aspirations of a nation. Based on the observation, there are seven major issues that need to be confronted and addressed in order to achieve this challenge. These issues are: recruitment, pre-service educator curriculum, governance and quality control, research, professionalism, educator's education, and professional development. These issues were examined individually and separately, but in execution it is being tackled holistically in the broader socio-cultural

context of Malaysia. This is because educating is essentially demographically bound and educators are 
agents and implementers of the education system. Hence, any transformational attempts must be context related.

TVET educators generally know little about the workplaces and the competence requirements of TVET graduates. In addition they do not have methodologies at hand, how such workplaces and competence requirements can be analysed. The same is actually true at national level for the purpose of TVET curriculum development. However, it is mandatory, that TVET educators have such methodologies at hand and master them in order to include the respective knowledge about requirements at work places in TVET teacher education, to include the teaching of the methodologies in TVET teacher education, so that teachers in their future job are able to analyse workplaces and competence requirements and to be able to run research on TVET curriculum development with the purpose to inform national TVET places / work processes in order compare competence requirements in TVET at the regional and international level, also with reference to upcoming regional qualification frameworks (Ismail et al., 2016). For this specific reason, a related industry experience is a compulsory for a TVET educator.

The present challenge is the preparation of high-quality TVET educators to execute Malaysia's policies and agenda and this concern brought about new challenges and demands, which require new capacities and knowledge on the part of educator. Different aspects of teacher quality are likely to be emphasized in different countries over different periods of time (Wang and Fwu, 2007). Today, the emphasis is less on quantity but more on quality.

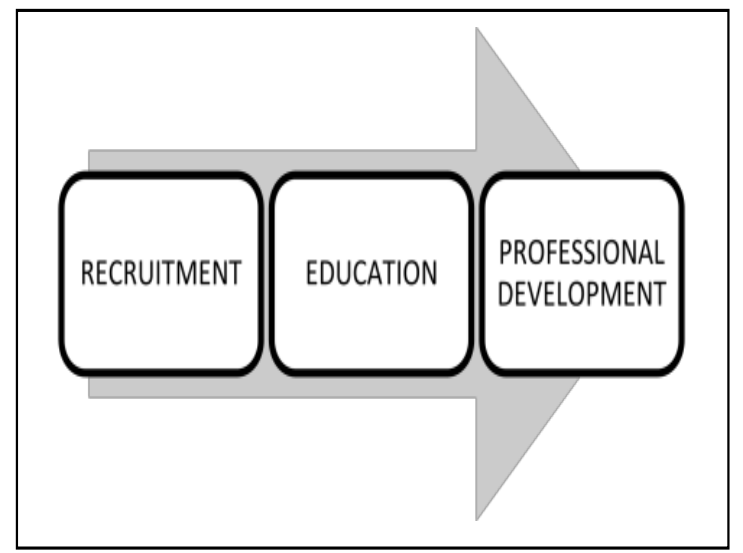

Figure 1: TVET educators' professional journey

Thus the challenge Malaysia faces is to ensure that we have a sufficient supply of well-equipped educators to propel the nation to a fully develop nation status. Sometimes we did have had starts, restarts and false starts due to policies that were not based on facts of research (Berg and Merrifield, 2009). Based on the above process scenario the issue of teacher education should be viewed from the perspectives of; recruitment, of pre-service education curriculum, governance and quality control, research, professionalism, educators education and professional development. Fallon (2010) states that students entering teacher education programs today are academically more competent and in Malaysia they are coming with better academic credentials, which is actually a positive problem. As places are limited a more stringent selection is needed. 


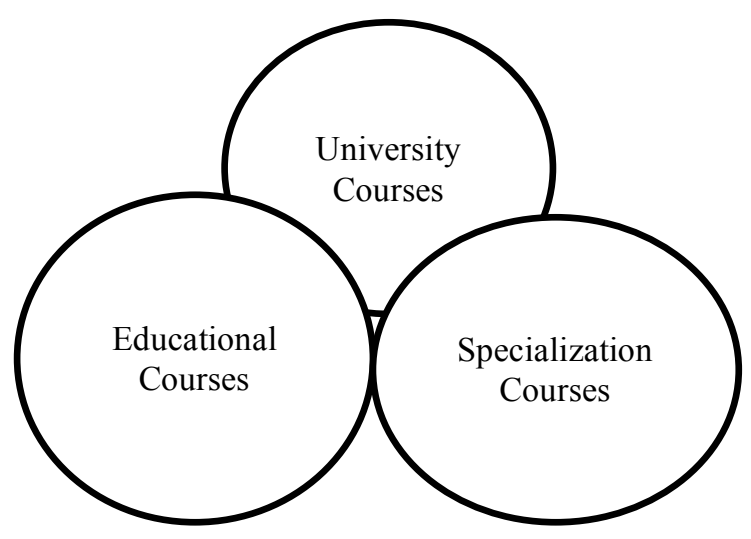

Figure 2: Pre-service educator curriculum

Courses for educator's education in Malaysian universities traditionally contain three main elements. The first element is the study of one or more academic, cultural, or aesthetic subjects for the purpose of continuing the students' own scholarship and to provide them with sound knowledge to be used in their subsequent teaching career. A second element is the study of educational principles, increasingly organized in terms of social science disciplines such as psychology, sociology, and philosophy. A third element normally consists of professional courses and school experience. We expect student-teachers to piece together the jigsaw to reconstruct knowledge and information, and make it a coherent whole for the purpose of teaching (Bolitho, 2002). Universities must provide a balanced curriculum in the form of a solid core of liberal studies, a rich program of general professional education within the larger plan of training for service as teacher or engineer, and an effective sequence of practical experiences for the professions (Brickman, 2010).

It is suggested to revise our TVET educator education curriculum so that we can produce educators who have deep and broad understanding of the learning processes of students and the various factors that shape this process. This includes the demand of the industry and the current transformation in ICT and Industrial Revolution. In order to do that, we need a specific competency that adhere to the occupational related area of an educator using a wide range of teaching knowledge, skills and values, including TVET assessment. Our educators should be able to adjust, adapt and be flexible in designing and implementing the curricula and learning environments.

Issue of educator's professionalism also being debated globally. Lack of professionalism can be deduced from the works of Hilferty (2008), Locke (2001), Reeves (2007), Rizvi and Elliot (2007), Wood (2007) and many other similar works, to be attributed to lack of any effective system of licensing, lack of agreed standards for performance, lack of incentives for competent and dedicated people to join the profession, work settings that do not provide a collegial atmosphere and appropriate set-up for the growth and development of 'professionalism' and assortment of prevailing systems of teacher education and the lack of interaction, which hinders standardization in the teaching profession.

\section{COMPETENCY OF EDUCATOR}

Competencies in this research was mainly adapted from three principles in Malaysia Teacher Standard (MTS) for quality educator. Competency profile should consists of a description of core competencies and a standardization of practice for professional educator (Khamis, Hussin, \& Nor, 2014). Meanwhile, Abdul 
Razak and Embi (2003) obtained the competency data from the literature review, document analysis and exploratory interviews that were then sorted according to categories and subcategories. Items that were similar in nature were collated and those without a category were separated. Competences are defined as a combination of knowledge, skills and attitudes appropriate to the context. Key competences are those which all individuals need for personal fulfilment and development, active citizenship, social inclusion and employment (Zarubova, 2014). The European Trade Union Committee for Education (ETUCE) describes quality teachers as equipped with the ability to integrate knowledge, handle complexity, and adapt to the needs of individual learners as well as groups. Teacher competences are built on "a concept of teaching as praxis in which theory, practice and the ability to reflect critically on one's own and others' practice illuminate each other, rather than on a concept of teaching as the acquisition of technical skills" (European Commission 2013, pp. 7-8). The European Reference Framework set the following eight key competences: 1) communication in the mother tongue; 2) communication in foreign languages; 3) mathematical competence and basic competences in science and technology; 4) digital competence; 5) learning to learn; 6) social and civic competences; 7) sense of initiative and entrepreneurship; 8) cultural awareness and expression.

TVET educator is the personnel that develop a person into a knowledgeable and able to be prepared for the nation development. There are many criteria of a good educator. In TVET, it is sometimes called as trainer, should have a certain ability in technical and vocational skill. TVET teaching competencies are defined as an integrated set of technical competency, learning and methodological competency, and human and social competency that are needed for effective performance in various teaching contexts and didactic approached (Spottl, 2009). These three clusters are basic components of holistic K-worker produced in Malaysia and was adopted from above. Ninety-eight competencies were identified from both the literature review and the focus group discussion method. These competencies reflected the range of attitudes, attributes, knowledge, and strategic and tactical skills that were required by electrical instructors (Ali, Kaprawi and Razally, 2010).

\section{RESULTS AND DISCUSSIONS}

\subsection{Job scope of Malaysian TVET educator}

In Malaysia context, TVET educators are primarily occupied in the teaching, learning and training, organization and management, delivery and assessment of a range of training and developing the curriculum in education programs. They are often engaged in providing input on training courses and on-going support as and when needed. They are also expected to involve in research and innovation activity while monitoring student's progress on certain project. More often than not, excellent educators act as resource providers and guides by delivering talks and workshops at training events and conferences. In short, the importance of educators' attitudes and the professional development of educators cannot be denied (O'Sullivan, 2010).

In the last decade, a number of professional standards and competencies for teacher educators have been developed. Unfortunately, not all of these standards are acceptable to the global professional communities of educators, since there are clear country specific standards that indicate that a one size does not fit all. Prior to the development of the competencies, benchmarking of the current and existing teacher's standard was conducted. There are two important model had been considered as the foundation of the Malaysia TVET educator's competencies development which are Malaysian Teacher Standard and the Regional TVET Teacher Standard for ASEAN Regional TVET Teacher Standard for ASEAN (2017). The model is depicted in Figure 3 and Figure 4. 


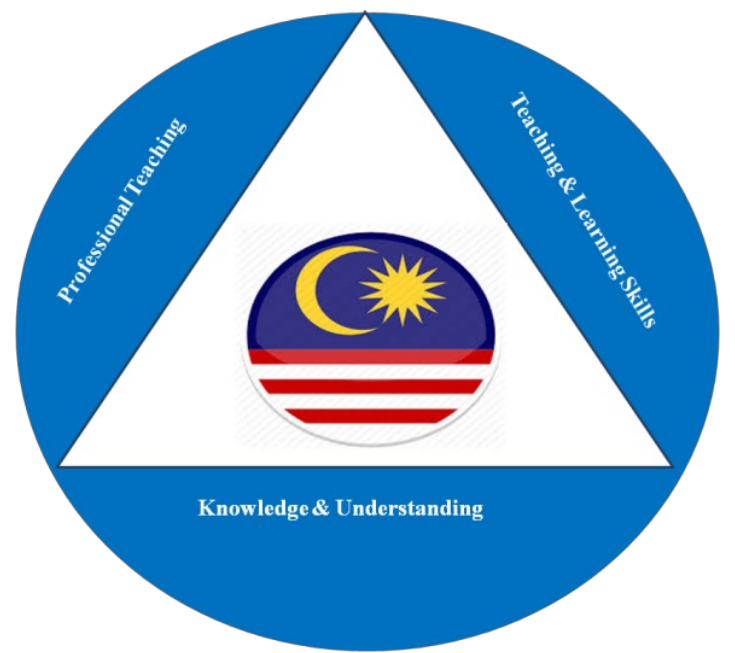

Figure 3: Malaysian Teacher Standard

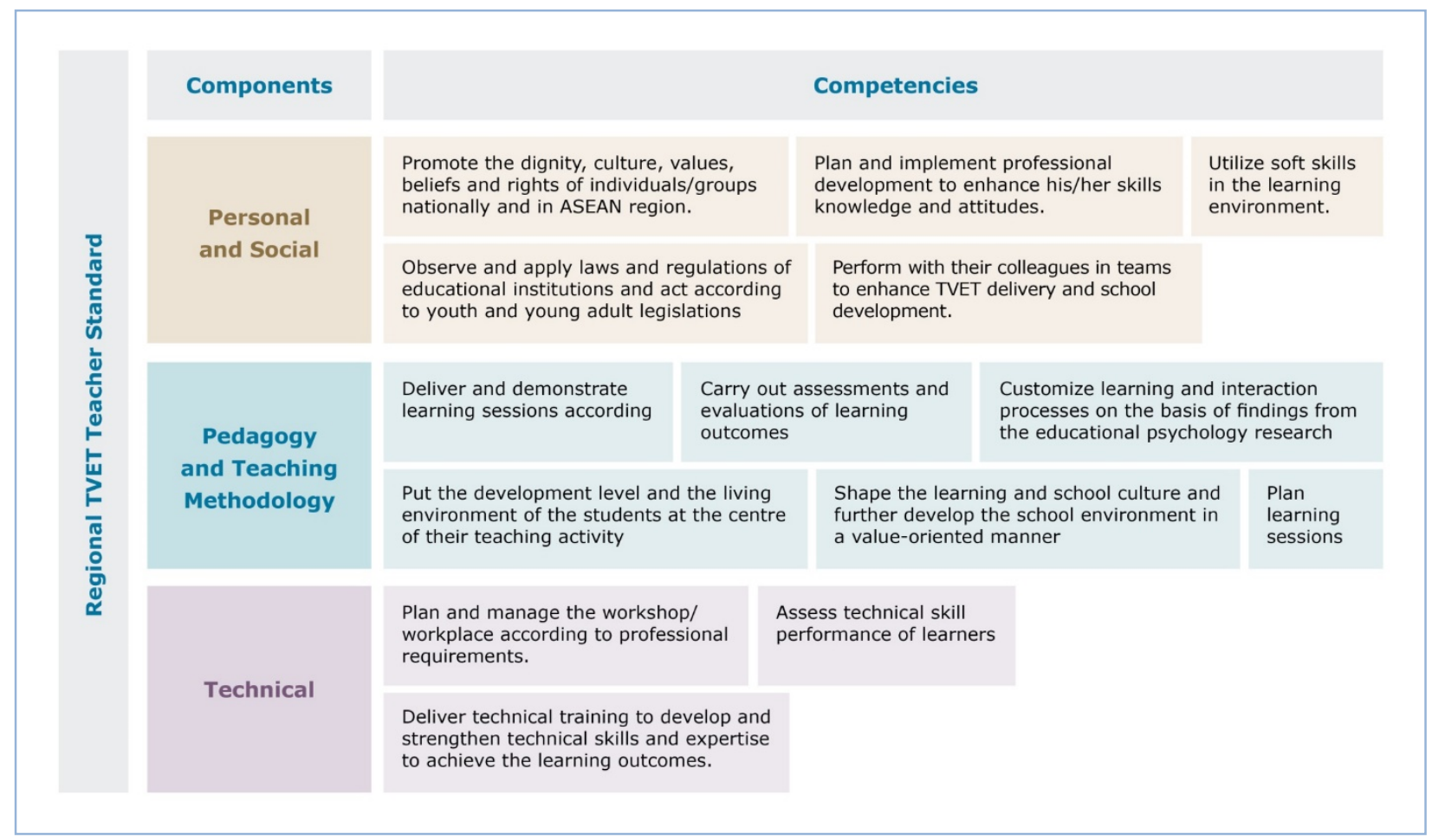

Figure 4: Regional TVET Teacher Standard for ASEAN

\subsection{Components of the Malaysian TVET Educator Standard}

The component of Malaysia TVET Educator competencies is to support the initial and continuing professional learning of all educators engaged in teaching and supporting learning in TVET area. The 
standard enables TVET educator to be recognized for their engagement with the minimum standard depending on their role and experience pertaining to TVET. These three components are designed to equip TVET educators with necessary teaching competency in TVET institutions as in Figure 5.

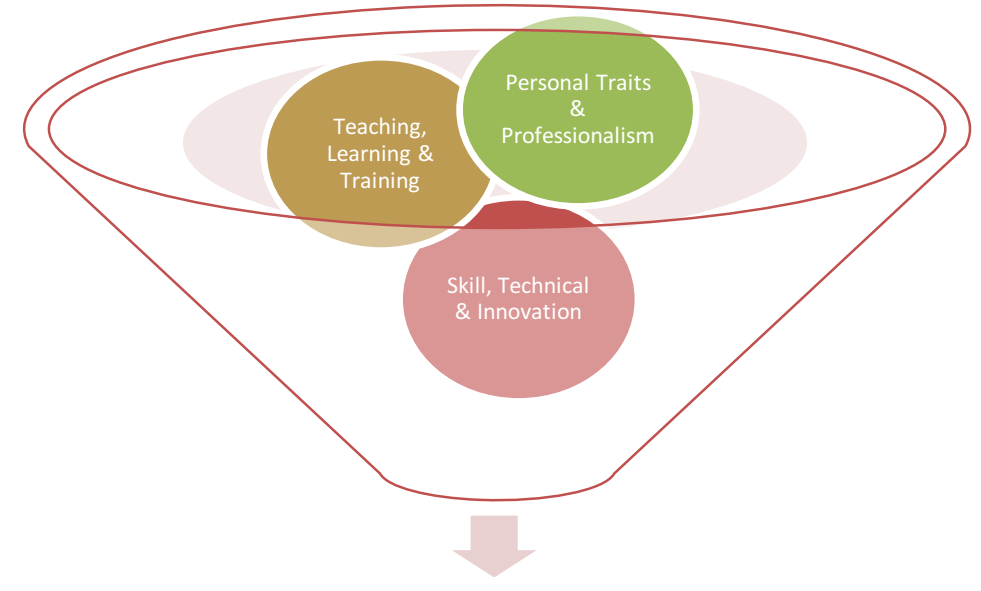

Figure 5: Main components for TVET Educator Standard

The main components of the TVET Educator competencies are 1) Personal Traits and Professionalism; 2) Teaching, Learning and Training; and 3) Skill, Technical and Innovation.

The Personal Traits and Professionalism Component is particularly dealing with the environment of the TVET educator at the TVET institution and within the educational system. It describes the competencies of a TVET educator to acquaint with the institution and the underlying system. This implies that besides developing high quality TVET classes, the educator is required to familiarise with the framework, conditions and opportunities for institution development and the need for permanent cooperation with colleagues, partner companies as well as other external training facilities and institutions. The educator needs to develop their professionalism with entrepreneurial, management, leadership and essential soft skills.

The Teaching \& Learning and Training Component of the TVET educator describes the pedagogical and subject-based methodological knowledge and skills according to the requirements of the professional and accreditation bodies. This requires a comprehensive understanding of didactic and methodological tools which meet the particular teaching circumstances according to the requirements of the core curriculum. The mastery and usage of modern media and technology such as $21^{\text {st }}$ century tools also fall under this context. This component encourages the application of effective qualification strategies and reflection and self-evaluation to ensure the understanding of teaching concepts, teaching plans and teaching implementation. The educator also need to have knowledge on the academic advisory practice.

The Skill, Technical and Innovation Component is a crucial part of every TVET training which focuses on the specifics occupational area of the TVET Educator. As educators experience theoretical and practical sessions in diverse ways, the emphasis on technical aspect is vital. The subject-didactics have to reflect this competency and thus support the educator's personality development. Industry experience, research and innovation and workshop management are the important elements in this component. 


\subsection{Core Competency}

One of the approaches that was adapted is the competencies in subject-didactic. Subject-didactic work opens up, reflects and structures the respective technical or scientific basic knowledge and related competences. It analyses their instructional significance. It is based on education plans, curriculum requirements, knowledge of pedagogy and psychology as well as on the requirements of professional training such as effective supervision (Ismail, Nasir, Hassan, and Masek, 2015) and leadership. The subjectdidactics will include the latest teaching and learning research outcomes and the respective resulting impulses and consequences for the design of adequate teaching and learning arrangements. Consideration also been made to aligned the curriculum design and teaching methodology on the latest technology in teaching and learning such as Online Learning, Massive Open Online Courses (MOOC) and blended learning. From industry's perspective, Industrial Revolution 4.0 and the requirement of occupational skills were embedded in the core competencies. The details of the core competencies for each of the components are explained in Table 1.

Table 1: Core Competency for TVET Educator

\begin{tabular}{|c|c|c|}
\hline \multirow{4}{*}{ 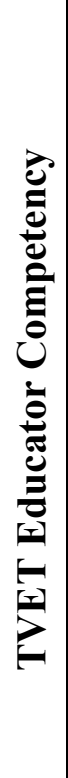 } & Main Component & Core Competency \\
\hline & $\begin{array}{c}\text { Personal Traits } \\
\text { and } \\
\text { Professionalism }\end{array}$ & $\begin{array}{l}\text { - Culture and Virtue } \\
\text { - Laws and Regulations } \\
\text { - Entrepreneurial and Soft Skills } \\
\text { - Professional Services } \\
\text { - Leadership and Management }\end{array}$ \\
\hline & $\begin{array}{l}\text { Teaching \& } \\
\text { Learning and } \\
\text { Training }\end{array}$ & $\begin{array}{l}\text { - TVET Curriculum Planning and Development } \\
\text { - TVET Curriculum Delivery } \\
\text { - TVET Curriculum Evaluation } \\
\text { - Academic Advisory }\end{array}$ \\
\hline & $\begin{array}{l}\text { Skill, Technical } \\
\text { and Innovation }\end{array}$ & $\begin{array}{l}\text { - Industrial Training and Project Supervision } \\
\text { - Research and Innovation } \\
\text { - Workshop and Laboratory Management }\end{array}$ \\
\hline
\end{tabular}

These components are the final result of the redefined and constructed elements from the model mentioned before which are the ASEAN TVET Teacher Standard, Malaysian Teacher Standard and National Occupational Skill Standard (Vocational Training Operation) (NOSS, 2017). Educator's competencies are understood as normative or evaluate basis upon which the actions of educators as professionals are judged as to their performance. Underpinning the idea of developing the educator standards within literature on educator's education is the idea of generating the competency (Pauline, Noor and Kung, 2012). Research in educator's education has shown that educator competence is a perquisite to effective teaching and learning due to its strong relationship to students' learning outcomes and achievement, and capable of developing student's soft skills. 


\section{CONCLUSION}

There is a prevailing belief that education has entered a new environment in which quality plays an increasingly important role (Abiddin and Ismail, 2014). Therefore, the TVET institutions need to be aware of the technology changes and provide effective support to the students (Ismail, Hassan, and Masek, 2015). TVET educator training and responsibilities in Malaysian context has evolved beyond its normal historical evolution. This paper describes the components and core competencies that could facilitate common understanding on the agreed practices and competency levels for educators in TVET institutions comprising appropriate components of knowledge, skills and attitude (KSA). These competencies will help TVET educators adapt and adopt best practices to meet the demand of society and contribute effectively to economic growth to the country. It is aimed to define the core competencies for TVET educators that comprehensively prepare their students for their transition to employment. Thus, these competencies when applied effectively, will ensure that Malaysian TVET educators is equipped with adequate skills and thus provide smooth transition from the institution to the world of work for their students. Furthermore, these competencies could act as a perfect guidance for the TVET institution to crosscheck and further align the competency of TVET Educator. On the other hand, it is can also be utilized by various ministries that offer TVET program. The core competencies in this paper are very useful in determining the competency level of an educator and identifying necessary training for the TVET Educator.

\section{Acknowledgement}

This project was initiated by the Ministry of Education Malaysia in line with the Malaysia Education Blueprint 2015-2025 (Higher Education) or MEB (HE). The authors would like to express a highly appreciation to the Ministry and committee members from Malaysia Technical University Network, Public Malaysian Universities, Malaysian Qualification Agency and Polytechnic \& Community College Department in developing the competencies. Special thanks also conveyed to the Regional Cooperation Platform (RCP) under GIZ-RECOTVET for continuous support and sharing on the Regional TVET Teacher Standard for ASEAN.

\section{Reference}

Abdul Razak, N. \& Embi, M. A. (2003). IT Competency for English Language Teachers in Malaysian Schools. Retrieved from http://www/eltrec.ukm.my/iJeLLT

Abiddin, N.Z. and Ismail, A. (2014). Exploring service and support needs in postgraduate education towards the higher education quality, Asian Social Science, 10(17), 52-56.

Ali, M., Kaprawi, N., \& Razzaly, W. (2010). Development of a new empirical based competency profile for Malaysian vocational education and training instructors. Proceedings of the 1st UPI International Conference on Technical and Vocational Education and Training. Bandung, Indonesia.

Berg, N., \& Merrifield, J. (2009). Illusive Competition in School Reform: Commentary on Merrifield's "Imagined Evidence and False Imperatives" and Merrifield's Reply. Journal of School Choice, 3(3), 290-306.

Bolitho, R. (2002). Teacher Training Institutes. International Conference on English Language and Development for Equity in the 21st Century.Kuala Lumpur, Malaysia: International Languages Teacher Training Institute.

Brickman, W. W. (2010). The Quest for Quality in Teacher Education. European Education, 42(2), 67-73.

Economic Planning Unit (2016). Eleventh Malaysia Plan, 2016-2020. Economic Planning Unit. Putrajaya, Malaysia.

European Commission (2013). Supporting teacher competence development for better learning outcomes. European Commission. Education and Training. 10 July 2013.

Fallon, D. (2010, October). A Golden Age for Teacher Ed. Kappan, 92(2).

Furlong, J. (2008). Making teaching a $21^{\text {st }}$ century profession: Tony Blair's big prize. Oxford Review of Education, 34(6), 727-739.

Vol. 10, No.2

December 2018| ISSN 2229-8932

Journal of Technical Education and Training (JTET) $\mid 47$ 
Hilferty, F. (2008). Teacher professionalism and cultural diversity: Skills, knowledge and values for a changing Australia. The Australian Educational Researcher, 35(3), 53-70.

Ismail, A., Hassan, R. and Masek, A. (2015). Generating elements of Supervisory Input Support via Exploratory Factor Analysis for effective supervision in Engineering Education. ICEED 2014 - 2014 IEEE 6th Conference on Engineering Education, Kuala Lumpur.

Ismail, A., Nasir, S., Hassan, R. and Masek, A. (2015). Investigating the Roles of Supervisory Working Alliance As Mediator for Overall Supervision Effective Using Structural Equation Modelling. Advanced Science Letters, 21 (5), pp. 1221-1224.

Ismail, A., Hassan, R., Masek, A., Hamzah, N., Ismail, I. M., \& Subramaniam, T. S. (2016). Implementation of vocational training into TVET's teacher program for national core standard. 2016 IEEE $8^{\text {th }}$ International Conference on Engineering Education: Enhancing Engineering Education Through Academia-Industry Collaboration. 28-31.

Khamis, N. Y. H., Hussin, S., \& Nor, N. F. M. (2014). Competencies of English for academic purposes educators at engineering universities: A conceptual framework. World Applied Sciences Journal, 30(30 A), 62-69

Locke, T. (2001). Questions of professionalism. change: Transformations in Education, 4(2), 30-50.

NOSS (2017). NOSS TVET Implementation \& Management Level 6 Putrajaya: Department of Skills Development (DSD).

O'Sullivan, M. (2010). Educating the teacher educator-A Ugandan Case Study. International Journal of Educational Development, $30,377-387$.

PricewaterhouseCoopers (2016). Study on the Demand and Supply of Human Capital Requirements on Technical Vocational Education and Training (TVET). Final Report Economic Planning Unit. Putrajaya: Malaysia.

Pauline, S. C. G. Noor, S. S. \& Kung, T. W (2012). The 'voices' of beginning teachers in Malaysia about their conceptions of competency: A phenomenographic investigation. Australian Journal of Teacher Education, $37,(7)$.

Reeves, J. (2007, March). Inventing The Chartered Teacher. British Journal of Educational Studies, 55(1), 56-76.

Regional TVET Teacher Standard for ASEAN (2017). Essential competences for TVET Teachers in ASEAN. SEAMEO VOCTECH and GIZ-RECOTVET.

Rizvi, M., \& Elliott, B. (2007). Enhancing and sustaining teacher professionalism in Pakistan. Teachers and Teaching: Theory and Practice, 13(1), 5-19.

Spöttl, G. (2009). Standardisation in TVET teacher education: Teacher education for TVET in Europe and Asia: The comprehensive requirements. Frankfurt: Peter Lang.

UNESCO UNEVOC (2013). TVET Standard Glossary of Terms. South African Qualification Authority (SAQA) South Africa.

UNESCO (2015). Recommendation concerning Technical and Vocational Education and Training (TVET). Accessed from: http://portal.unesco.org/en/ev.php-RL_ID=49355\&URL_DO=DO_TOPIC\&URL_SECTION=201.html

Wang, H. H., \& Fwu, B. J. (2007). In pursuit of teacher quality in diversity: A study of the selection mechanisms of new secondary teacher education programmes in Taiwan. International Journal of Educational Development, $27,166-181$.

Waters, M. (2009). Climate Change - global warming or global yawning? Education Review, 21(2), 60-72.

Wood, D. R. (2007). Professional Learning Communities: Teachers, Knowledge, and Knowing. Theory into Practice, 46(4), 281-290.

Zarubova, H. (2014). Higher education teacher competences in view of the changing social conditions. Edukacja ustawiczna dorostych, 4(87), 92-100. 